УДК 008 (439): 37 (439)

DOI: $10.24144 / 2524-0609.2020 .46 .212-219$

Dr. Juhász Erika

Head of Department, Associate Professor, University of Debrecen, Hungary

Faculty of Humanities, Institute of Education and Culture, Department of Adult Education and Cultural Management

Director, senior researcher, Center for Cultural Research and Education, Hungarian National Cultural Institute juhasz.erika@arts.unideb.hu

ORCID ID: http://orcid.org/0000-0002-3110-2574

\author{
Bordás István \\ President of Association of Hungarian Cultural Managers \\ bordas@zemplenimuzsa.hu
}

\title{
THE MAIN CHARACTERISTICS OF CULTURAL EDUCATION IN HUNGARY
}

Abstract. Hungarian cultural education is a special system of concepts and activities that is unique in Europe. Its historical roots can be traced back at least to the first third of the 19th century, the Hungarian Reform Era. The institutional system and the legal background of the supply of cultural tasks are completely established. Laws refer the supply of these tasks to the authority of local governments. However, available data show that besides the nearly four thousand local government institutions, there are two thousand non-governmental and church-run cultural education organizations operating in Hungary. Our present study aims to give an overview of the special characteristics and the current situation of the institutions in the scope of local governments based on application of genneral and special research methods: historical, systemic and structural-functional analysis. On the one hand, it takes into account the information provided by the mandatory statistical data. Furthermore, data from professional publications and conferences on cultural education are also important sources. However, the personal experience of the authors of this study cannot be left out of consideration either. Performing tasks as professional supervisors and qualifying auditors for nearly two decades is an important basis of the findings. Based on the results of the research, we formulated some proposals for professional improvement: (1) Creating a registration system for cultural education institutions, (2) Developing the supply of cultural tasks in sub-counties, (3) Fostering the implementation of quality art programs. We believe that these improvements would also help research in the cultural field: the development of a registration system would help in the continuous monitoring of cultural institutions, and action research could be linked to new methodological developments for in-process development.

Key words: culture; cultural education; Hungary.

\section{Introduction}

Hungarian cultural education is a special system of concepts and activities that is unique in Europe. Its historical roots can be traced back at least to the first third of the 19th century, the Hungarian Reform Era [7]. Although the historical storms of the last two centuries have brought many pitfalls and obstacles to the development of this system, we can firmly say that today this network serves the daily cultural and community needs of the Hungarian citizens the most effectively and extensively. Statistics splendidly prove this statement. According to the latest data aggregation, cultural education organizations welcomed 67 million visitors in one year and house more than thirty thousand cultural communities.

The institutional system and the legal background of the supply of cultural tasks are completely established. Laws refer the supply of these tasks to the authority of local governments. However, available data show that besides the nearly four thousand local government institutions, there are two thousand non-governmental and church-run cultural education organizations operating in Hungary.

Our present study aims to give an overview of the special characteristics and the current situation of the institutions in the scope of local governments based on application of genneral and special research methods: historical, systemic and structural-functional analysis.

On the one hand, it takes into account the information provided by the mandatory statistical data [4]. Furthermore, data from professional publications and conferences on cultural education are also important sources. However, the personal experience of the authors of this study cannot be left out of consideration either. Performing tasks as professional supervisors and qualifying auditors for nearly two decades is an important basis of the findings.

This study only touches the cultural education activities of non-governmental organisations. The analysis of relevant data and information is outside the scope of this study [6].

\section{Results and Discussion}

1. The Legal Background of the Supply of Cultural Tasks

The operation of the network of cultural education institutions, which covers the whole territory of Hungary, is entirely regulated by law. The environment for the operation of the activity appears at all levels of legislation. The need to provide cultural and community services to the citizens appears even in the Constitution. The daily operation of cultural education is entirely regulated by the related government and ministerial decrees.

In terms of its history, the legal regulation of cultural education activities dates back to the era of socialism. The institutional system of the era, which was finalised by the mid-1970s, as well as the related professional developments, made it necessary to establish a legal environment for the activity. As a result, the first cultural education law was passed in Hungary in 1976 [1].

If we examine the current legal environment, it can be stated that it regulates the prerequisite, the content, the forms and the professional and material environment of the supply of cultural tasks from the highest legal level down the way to the authority of municipal legislation.

The Constitution of Hungary Article XI. is worded as follows:

(1) «Every Hungarian citizen shall have the right to education.

(2) Hungary shall ensure this right by extending and generalising public education, providing free and compulsory primary education, free and generally available 
secondary education, and higher education available to every person according to his or her abilities, and by providing statutory financial support to beneficiaries of education».

Consequently, two statutory regulations also deal with the supply of tasks. Act CLXXXIX of 2011 on the local governments of Hungary obliges local governments to supply cultural tasks. Section 13 of this Act contains the following: «13. section (1) [1] Local government tasks to be performed in the field of local public affairs and locally available public tasks are in particular: 7. cultural services, in particular, the provision of public library services; support for cinemas, performing arts organizations, protection of local cultural heritage; supporting local cultural education activities»».

The detailed regulation of cultural activities at the statutory level is provided by Act CXL of 1997. In accordance with the Constitution, the preamble to this Act reads as follows: "Cultural heritage assets are irreplaceable sources of knowledge of our past and present, inseparable components of the national and universal cultural heritage as a whole; their intellectual possession is a fundamental right of every human being. It is the responsibility of society at all times to protect, preserve and maintain the values related to this concept and to make them widely and equally accessible to the public»».

Moreover, several legal acts have been drafted on the regulation of the conditions of different sub-areas of the supply of cultural tasks. In summary, these areas are the following:

- Requirements for the operation of basic cultural education services and institutions.

- Qualification requirements for employees in cultural education institutions.

- Further professional training of employees in cultural education institutions. tivities.

- Professional supervision of cultural education ac-

- The quality management system of cultural education institutions [9].
2. The Economic Background of the Supply of

\section{Cultural Tasks}

The economic background of the supply of cultural tasks comprises the baseline support provided as a state contribution by law, the local government budgets, the amount of national and mainly European Union or other international tender revenues and the income of the institutions.

The state provides baseline contribution to local governments to support mandatory cultural education and public collection services. The amount of this support is currently set to be 1,251 HUF/person in the budget of Hungary. Less contribution is supplied to the budgets of the capital city and the county seats (Support for the cultural education tasks of the county seats and the Municipality of Szentendre is HUF 459/person, support for the museum, library and cultural education tasks of the Municipality of Budapest is HUF 692.2 million, and support for the cultural education tasks of the district municipalities is HUF 410/person.) However, to provide more support for the supply of tasks in small settlements, this amount cannot be less than $1,800,000$ HUF per year.

From 2021, a significant increase can be observed in the amount of the baseline contribution: $2,170 \mathrm{HUF}$ per person, but a minimum of 2,270,000 HUF per year. At the same time, the amount of the minimum baseline support in the capital city and the county seats is also increasing (Support for the cultural education tasks of the county seats and the Municipality of Szentendre is HUF 950/person, support for the museum, library and cultural education tasks of the Municipality of Budapest is HUF $1,171,000,000$, and support for the cultural education tasks of the district municipalities is HUF 560/person). The amount of the baseline contribution has constituted a source of 14-15 billion HUF for local governments in the recent years, and its increase in 2021 is a significant step forward in establishing the economic foundation for the supply of cultural tasks (Fig. 1).

\section{County distribution of the increased amount of money to be spent on culture as a result of the increase in the minimum cultural baseline contribution, 1 January, 2021 (million HUF)}

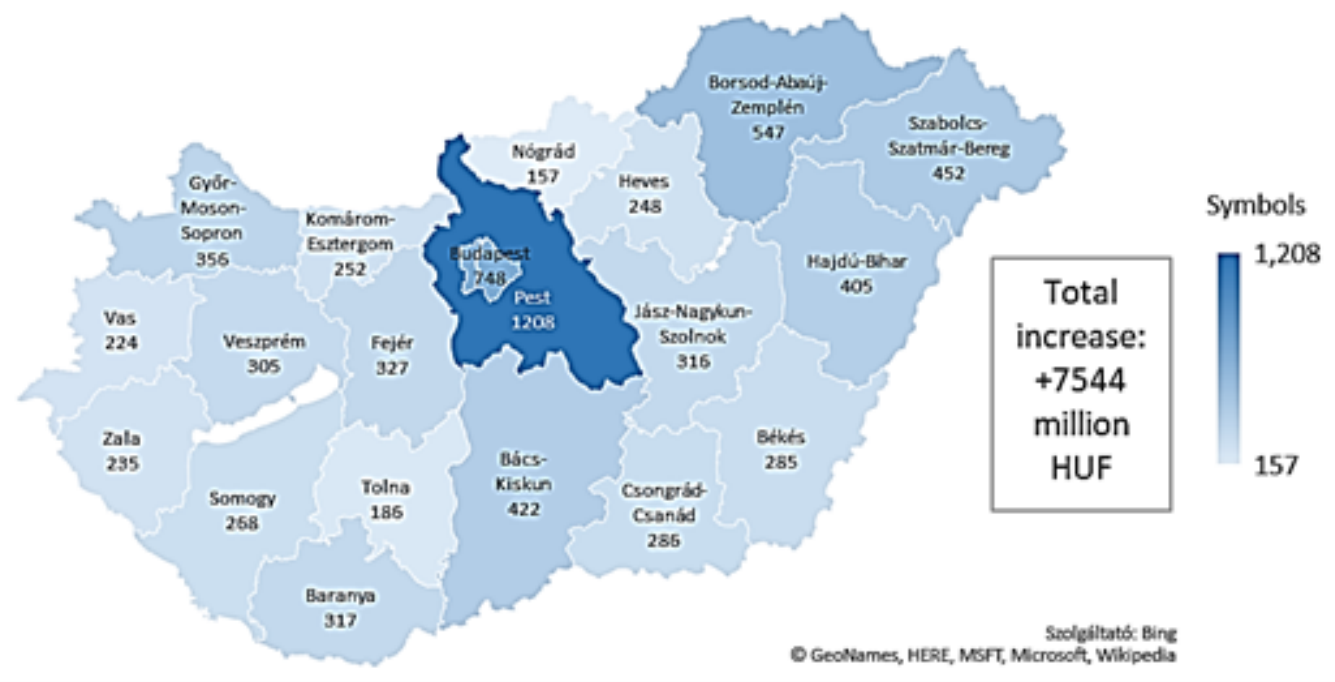

Fig. 1.

Source: 2020 database of the National Institute of Culture 
However, in addition to this contribution, the local governments themselves also finance the supply of cultural tasks. Although detailed statistics are not available in this respect, experience shows that selffinancing of local governments often exceeds the baseline contribution. In the case of small settlements, this is on average half or two-thirds of the amount provided by the state. In many cases, cities double or triple the amount of the baseline support. County seats and the districts of the capital city also provide multiples of the baseline support for the supply of cultural tasks.

Moreover, the cultural education organizations of the settlements, - although to different extents - show significant tender activity to acquire Hungarian resources and draw down EU funds.

National financial sources to be mentioned are first of all the tender programs of the National Cultural Fund of Hungary. The resources of the National Cooperation Fund are also available for non-governmental cultural education organizations.

Local governments can also apply for the so-called cultural education interest-raising support directly from the sectoral ministry (This support will be HUF 300 million in 2020, but from 2021 the method of drawdown will be structurally changed).

European Union tendering systems are also available to these organizations. However, it can be affirmed that in the 2007-2013 budget period, due to the characteristics of the tender constructions, a larger amount of funding was drawn down from these funds than at the present period. According to the available reports, the cultural education institution system was able to attain nearly 30 billion HUF for professional and infrastructural development (The determinate tender constructions of the drawdown for funds in the field of culture: 2004-2006. Human Resources Development Operational Program, 2007-2013. Social Renewal Operational Program, Social Infrastructure Operational Program, 2014-2020. Human Resource Development Operational Program). The support policy of the current budget period is mainly focused on human resources development, therefore the application rate is much lower. However, a detailed summary of this can only be prepared at the end of the budget period.

Also, especially the cities generate their revenue from event tickets, marketing activities, rental and other services, which is also a very significant source.

3. Daily Operation of the Supply of Cultural Tasks in the Settlements

According to the complete statistical year of 2018, there are 3,177 local governments in Hungary. This number includes county seats or districts of Budapest with hundreds of thousands of inhabitants as well as small villages with only a few hundred inhabitants. Law does not make any distinction among the settlements concerning the mandatory supply of cultural tasks. However, obviously, the legal environment that specifies the way and circumstances of the supply of tasks sets different conditions for settlements of different sizes. Below, we take into account the characteristics of cultural education activities carried out on different types of settlements. We endeavour to present the equipment and staff requirements of the institutional system operating there, we touch on the most important innovations implemented in the segments of the institutional systems.

a) The State of Cultural Education Activities in Small Settlements

According to the available data, currently, 2,809 settlements with village status operate in Hungary. Among them, there are 1,739 villages with less than 1,000 inhabitants, owing to the special characteristics of the Hungarian settlement structure. At the same time, there are also settlements with village status with a population of over 5,000 .

The former are mainly located in Borsod-AbaújZemplén, Somogy and Zala counties. The latter are characteristic of Bács-Kiskun, Szolnok, Csongrád, Pest and Hajdú-Bihar counties (For instance, there are 358 settlements in Borsod-Abaúj-Zemplén county, of which only 28 are towns. There are 60 settlements in Csongrád county, of which 8 are towns ).

The legislation determining the conditions of the basic services obligates these settlements to operate the cultural education scene. According to the statistics of 2018, there are 2,661 community scenes in these settlements. If we assume that the larger villages supply the obligatory tasks through institutions, then there are nearly 200 local governments in this circle that currently do not comply with their legal obligations.

Commonly, village community scenes (several names are common: community houses, culture houses, village houses, community centres) accommodate each segment of the supply of cultural tasks. They are clubs, libraries, theatres or event houses of the settlements at the same time. Although in the last one and a half decades there have been several attempts to encourage local governments to cooperate in the field of culture at subcounty level or only in a smaller circle of settlements, this has only been partially achieved.

Regarding the content of the supply of tasks, this type of settlement shows the biggest differences. Limiting cultural education tasks to one event per year (village day) is just as common as the bustling community life with an extremely diverse community, cultural and entertainment events. Experience shows that this does not primarily depend on the size of the settlement. Rather, it depends on the activity of the local citizens, the commitment of the settlement leaders to culture, and the availability and personality of cultural education specialists.

As for the personnel, the small settlement community scenes employ only a few full-time or parttime workers. Employment on a contract basis is much more typical. However, in general, we can state that the community and cultural life of these settlements largely depend on voluntary work.

This situation is significantly changed by the Decree of the Ministry of Human Capacities (hereinafter: EMMI), which regulates the conditions of the supply of tasks [3], as by 2021 this legislation will make it compulsory for all local governments to employ cultural education specialists with at least a secondary level professional qualifications.

Community scenes are not independent institutions. In most of the cases, their economy is incorporated in the budgets of the local governments.

By involving several different sources, the development of the cultural education infrastructure of the village settlements has taken place in the last two decades or so. In the second half of the 1990s, it was supported by the so-called revitalization program. The first decade of the 2000s was about the public asset program in this respect. From 2010, EU funds were involved (IKSZT, Regional Settlement Development Programs) as the source for the renovation of culture houses. In the period after 2018, the Village Development Program of the Hungarian Government provides an opportunity to modernize the institutional infrastructure. In general, it may be noted that in the last 25 years the community scenes have been modernized in settlements, where there has been a sufficient demand from the population and the management of the settlement. At the same time, it 
can be pointed out that the groups of settlements located in the most disadvantageous areas of Hungary are still in a serious situation both in terms of the content of the service and the conditions of the infrastructure. The reason for this is complex, which could be primarily the combination of economic and social deficits.

In the last one and a half decades, the most important professional innovation in the operation of cultural education scenes is the emergence of integrated community service venues and the establishment of the conditions of their operation. This was supported by the Agricultural and Rural Development Fund of the European Union. In the two-stage tendering procedure, 1,003 applications were submitted from the approximately 3,000 eligible settlements. Out of the submitted applications, 635 developments were funded by the contributing organisation. Thus, we could say that the cultural infrastructure in these settlements was completely modernized in a way to facilitate the introduction of additional services. So far, experience shows that these so-called Regional Settlement Development Programs also offer non-cultural services to residents (primarily of a social nature), but they function as community houses. However, the professional requirement set out for the Regional Settlement Development Programs has triggered a change of attitude in the cultural supply of the settlements. This change of approach first and foremost requires the emergence of a community and sociocultural approach in the daily operation of the service.

b) Characteristics of the Supply of Cultural Tasks in Urban Settlements

There are 322 urban settlements in Hungary. Significant differences can be perceived also in the group of these settlements, both in terms of the level of development and population size. There are 202 towns with a population of less than 10,000. There are quite a few of them with a population of less than 5,000 (90). The supply of tasks of the lower segment of this group of settlements is closer to that of the villages than to those of larger cities. However, it can be seen that in the case of the 152 cities which function as sub-county centres, cultural education mainly acts as a strong cohesive and developing force of the settlements. To a different extent, but in almost all the cases the institutions operating in these places undertake sub-county functions as well. In the towns - except for a few unlawful exceptions - we are talking about institutions, as Act CXL of 1997 makes it mandatory for towns to establish and maintain a cultural education institution.

Generally, it can be stated that in terms of the number of employed professionals, the applied resources, and the number of operating institutions, the cultural education organizations operating in these settlements form the backbone of the supply of tasks in Hungary.

Cultural education institutions typically operate as multifunctional organizations in these settlements. In addition to the cultural education functions, they accommodate the activities of the library and, if possible, the cinemas as well. Many times they also supply the tasks of museum institutions. Due to the changes in the legislation regulating the management conditions of local government institutions, urban cultural institutions are not independent financially. Although local governments made some effort in the early 2000 s to transform local government institutions into non-profit business companies, this has not become as widespread as in larger cities. In quite a few cases the former business company was even «reinstitutionalized».

In terms of infrastructure developments, this group of settlements has been the least supported in the last two decades. Although many of the cultural houses operating in these settlements are in good technical condition, a general modernisation program has not been implemented recently. Neither national nor European Union funds were available. Consequently, local governments tried to modernize or technically maintain their cultural institutions on their own.

In terms of the implemented cultural programs, these organizations cover almost the entire range of professional activities. Concerning the task structure, both according to the previous Cultural Act and the recent amendments to it, we can claim that full-scale work is performed in these organizations.

In the towns, the supply of professionals is relatively good. The vacancies are mostly taken by professionals with secondary or higher qualifications. There is a significant number of employees with a master's degree in the profession. Nonetheless, the ageing professional staff and the recruitment of new staff will be an increasing problem of the supply of urban tasks in the coming years.

After studying the financial sources of the professional activity, it can firmly be stated that the local governments supplement the budget of the institutions by two to three times the baseline contribution. Analysing the ratio of the institutions' own revenue, it comes clear that these type of institutions are the ones that expand their budget with this resource to a significant extent. Of course, this shows significant differences depending on the economic power of the settlement.

Urban institutions are extremely active both in the mobilization of European Union funds and in the use of national tender grants. These organizations are persistent applicants to the National Cultural Fund of Hungary, and also, when examining the submission of European Union applications, a large number of applicants can be found from these settlements.

When considering the professional operation of urban culture houses in the last two decades, several innovation bases can be found. The emergence of available EU funds has generated significant professional development in the profession. Not only did it mean an increase in resources, but also strongly motivated the institutions to apply the PCM approach and to improve the documentation of their work.

Though from another direction, the introduction of the cultural education quality system also strengthened these processes. This is true even in those cases when the institutions in question did not participate in the qualifying process. Professional consultations and professional public opinion strongly push the organizational culture in this direction.

Owing partly to the European Union funding, significant professional developments took place in these institutions in the early 2010s following the LLL approach. However, due to the continuous restructuring of vocational and adult education, recent innovations have been significantly devalued in the past years.

The above-mentioned sub-county function of the supply of tasks is not strengthened legally or by the cultural policy in their daily operation. Nevertheless, the institutions of the towns that function as sub-county centres more or less supply sub-county tasks. This is mainly because the sub-county centres themselves are the natural centres of a group of settlements. Although the Public Asset Program started in 2006, was discontinued after 2010, the professional development and relations implemented through it continue to operate to some extent. It is natural for the "cultural workers» of the small settlements around the cities to ask for help from the staff of the urban culture houses. They often have the expertise and a network of contacts accumulated over several decades, which they can make available to their 
colleagues in need. Specialists of the institutions often perform this activity outside the work schedule and out of professional commitment.

c) The Agoras, the Flagships of Cultural Education

The establishment of agoras has been the most significant infrastructural and professional development program in cultral education in the last 20 years. This European Union project involved 13 out of the 23 county seats (Two more agoras were formed as socalled pole agoras (Debrecen, Győr). They are centers of scientific education experience. A planned development (Miskolc) was not implemented.). Except for one (Hódmezővásárhely), the transformation of the urban cultural centres of the county seats meant not only their infrastructural modernization and expansion but also the creation of a new professional approach, which placed the supply of cultural tasks in large towns on new footings. It is based on the idea to create a complex service structure in culture and all its border disciplines that is based on the community. Regarding the forms of financial management, the newly established institutions mostly operate as non-profit Ltd. This means, that financial management solutions beyond the potential of institutions are available. This can be a good opportunity if the organisations can make use of the profit-generating ability of cultural life in large cities. Thus, the opportunity is given to use the generated profit to fund community and socio-cultural programs that are important for the society, but difficult to fund. Most of these agoras take advantage of this opportunity. Consequently, besides the full range of «classic» cultural education activities, these professional organizations also provide other services to the residents of large cities. For instance, youth or family support projects, talent management and touristic tasks are common.

In line with the original intention of the Agóra Program, these institutions should also supply regional cultural tasks. However, according to the findings of the latest cultural education supervision study, they are not always able to fulfil this task. The professional report of the supervision states that this does not depend primarily on the intentions of the specialists of the institution but on the willingness of the local governments to finance them.

During the development, building complexes of European standard have been created to mediate culture, which themselves attract citizens. It is quite common that the annual number of visitors is over two hundred thousand. This heartwarming fact, however, raises a problem that local governments in some measure are unable to solve. Namely, the high rate of usage quickly amortises the buildings and the equipment. They need refurbishing faster than in normal cases, but the financial source is not always available.

d) Daily Operation of Cultural Education in the Capital City

Budapest, with a population of nearly two million, occupies a special position in the supply of Hungarian cultural tasks. The size and economic power of the city offers a huge variety of market-based cultural services. Therefore, one may raise the question of whether there is a need for the operation a «classic» system of cultural institutions in this metropolis. Daily practice in the field proves that there is a great need for it for several reasons. On the one hand in the decades following the political changeover, the need for a so-called district identity has strengthened. Its development and content supply cannot be market-based. It is considered an important cultural issue by the municipalities of the districts. On the other hand, a significant proportion of the residents are unable to satisfy their cultural needs using market-based services. Firstly because of financial reasons, secondly, because the outspread territory of the city causes access problems, thirdly, there are cultural services that cannot work market-based.

All the 23 district municipalities of Budapest maintain cultural education institutions. In the last 15 years, most of these institutions have been converted into non-profit companies. Nevertheless, the district municipalities financially support cultural activities with considerable amounts. Professional and financial problems occur mainly in cases where the cultural education institution does not operate as an independent organization but as part of a multi-service enterprise established by a local government.

Even with all this in mind, local governments have carried out significant modernization in these institutions almost everywhere, resulting in considerable improvements in the conditions of operation. However, it is difficult to coordinate the professional activities of institutions operating in multiple premises (especially on the outskirts), which makes the job more difficult. Cultural education institutions with even 10 or 15 premises are also common in the capital. Although organizing programmes is made more difficult, the fact that residents have easy access to the services offered by these institutions is one of the greatest strengths of the institutional system.

It is also true for the cultural education institutions of the municipalities of the capital that the local governments financially supplement the baseline support with considerable amounts. They are well-staffed with professionals, but in recent years there has been a tendency for well-educated, mainly young professionals to leave the profession due to the emergence of vacancies in other professional fields offering much greater earnings in fields where any universal qualification is welcome. In some cases, this also generates a shortage of suitably qualified specialists.

Analysing the professional innovations, the cultural display of services to be found in Budapest inspires professionals. Without continuous renewal and offering newer and newer services, these institutions would soon lose their audience and communities in the city. This increase in the supply - as in the case of agoras - mainly focuses on the border disciplines of cultural services. Institutions effectively use the benefits of their accessibility and the socio-cultural needs of those living in the area. Several forums have highlighted that one of their key tasks is to reduce cultural inequalities.

e) A Special Civil Cultural Education Network, the Association of Territorial Cultural Institutions

According to cultural education statistics, more than 2,400 non-governmental organizations (foundations, associations) accomplish cultural education activities. Comparing this number with the number of cultural education agreements (441), it comes clear that the nongovernmental operation of cultural education institutions is not widespread. However, there is a special network of institutions in Hungary, which is organized on nongovernment grounds - though with the help of significant support from the state. The civil partnership coordinated by the Association of Territorial Cultural Institutions is based on the former trade union cultural houses. The 60 cultural houses were maintained by various sectoral trade unions before the political changeover. After the transformation of the trade union system, the institutions were left without an owner. Further operation and professional tasks were provided by creating a nongovernmental organization for each institution, which then founded the Association of Territorial Cultural Institutions (TEMI). The Hungarian state supports these 
institutions through this umbrella organization. The amount provided by the central budget is distributed by TEMI via tenders.

In several smaller settlements, these culture houses are the only task suppliers. In larger cities, special or stratified services are provided that complement the activities of basic service institutions. Their activities do not differ from the operation of institutions maintained by local governments. Their professional and innovation problems are also similar.

Their special problems, however, are rooted mainly in the operation form of the association and the lack of funding beyond the TEMI support. Local governments either do not support them financially or provide only a small amount of support, though in many cases they also supply tasks of the settlements. Another special problem of these institutions is that the property they use is not their own, they are mostly state-owned. Thus, financing and performing maintenance and modernization tasks is difficult.

f) The Institution of the National Supply of Professional Tasks

According to the Cultural Constitution, the National Institute of Culture (The exact legal name: NMI Institute of Culture Nonprofit Public Benefit Ltd.) should provide background support and professional development tasks to the cultural education profession. The organization is the intellectual successor of the Folk Education Institute, which was established in 1946 (the first president of which was Gyula Illyés). It operates as a business organisation, established by the Folk High School Foundation of Lakitelek, within the framework of a contract on public supply of tasks.

The national cultural education organization covers the whole territory of Hungary through its county directorates. Moreover, its activities expand to areas inhabited by Hungarians beyond Hungarian borders. It effectively cooperates with the cultural education organizations of the regions and the Public Cultural Roundtable of the Carpathian Basin, which was established together with them.

Its activities include the implementation of training tasks in the framework of professional development and professional background support. Its professional and vocational training programs are performed all over the country. To train professionals for the future, it cooperates with higher education institutions.

It has an extensive information portfolio to inform the professionals. It makes use of the potentials of traditional publishing (e.g.: Szín journal, professional publications) as well as the tools of modern information technology (e.g.: social network sites, Kulturális Szemle online journal, Knowledgebase in community culture (Tudástár a közösségi müvelődésben) online publication series).

In collaboration with the universities, it has a complex research program to foster the development of the profession. The institute regularly organizes data collection and processing, publishes its research results and uses them to regenerate the legal environment, form support strategies, and update training contents.

It plans and implements independent cultural education projects among the Hungarians in the Carpathian Basin, such as the Meals for fresh mothers (Komatál) program, the Needlework (Újra öltünk, örökítünk) program, the Barn Theatre (Pajtaszínház) program. In these programs, the institute collaborates with a wide range of cultural education institutions and community scenes (Further information can be found on the website of the organisation: www.nmi.hu).
4. Training and Further Training of Cultural Education Professionals [6]

To meet the needs for specialists in cultural education, in- and out-of-school secondary and tertiary education courses are available.

According to the National Training Register (OKJ), it is possible to obtain a vocational qualification in cultural education at secondary and tertiary levels. Such trainings are organized market-based by several institutions, but the largest trainer is the National Institute of Culture.

Higher education cultural education qualifications could be obtained at Hungarian higher education institutions for more than 40 years. After a few gap years, the entire higher education structure provides students with the opportunity to obtain degrees of cultural education at various levels. At the beginning, the training followed the public education and cultural education approach. In the 1990s, this emphasis shifted towards a managerial approach and adult education. The approach of the entire higher education structure of cultural education, which was re-established a few years ago, is primarily characterized by a community approach.

At present, the community coordinator major is available at BA level with the following three specialisations: Cultural Community Coordinator, Youth Community Coordinator, Human Developer. Also, a community education teacher course is available after the final exam in an undivided program in combination with other teaching majors. In the master's program, andragogy and cultural mediation can be studied at universities. Cultural education specialists can obtain a doctoral degree within the framework of disciplines of education science.

Professionals already in the profession are required by law [4] to attend professional trainings. This requirement can be met by participating in professional trainings (in tertiary or higher education), language training to obtain a language exam or a professional further training program. According to the Act on Programs [5], only professional further training programs approved by the Accreditation Committee of the EMMI State Secretariat meet these requirements. At present, the largest professional training organization is the National Institute of Culture.

Conclusions and Perspectives for the professional improvement and further research

1. Creating a registration system for cultural education institutions

According to Act CXL of 1997 and the related legal regulations, settlements are obliged to operate an organisation to supply cultural tasks at their level of administration. Studying the statistics of cultural education and the data provided by the local governments, we can conclude that the number of cultural education organizations cannot be defined. However, the above-mentioned laws set out exact requirements for the professional and infrastructural conditions of each cultural education organization depending on their type. Thus, the type of institution can easily be determined by the requirements it has to meet in agreement with the conditions set by the resources and laws. For the sake of transparent and accurate data provision, it would be necessary to establish a mandatory registration system for the different types of cultural education organizations. Such systems operate in the case of public collections, which are also regulated by the Cultural Constitution. Establishing the registration system of cultural education institutions would not only serve the accuracy of data but would also standardize the register of the types of institutions operating in the system of cultural basic services. 
2. Developing the Supply of Cultural Tasks in Subcounties

Due to the differences in the settlement structure and the level of their development, the task suppliers of small settlements have different opportunities, professional and financial support. Cultural education institutions with sub-county headquarters supply subcounty-type of assisting tasks in many places, due to their cultural relations and their natural role as a catchment area in the agglomeration. The extent and quality of these roles are extremely variable. However, obviously, this type of supply is needed, especially in the underdeveloped regions. The need for such supply is likely to be enhanced by the fact that local governments will comply with their legal obligations and will employ professionals to supply local cultural tasks. The idea of the development proposal is to launch a pilot project to form a mentoring support network at sub-county level among the employees working in the settlements. The sub-county-based cultural institutions would employ a part-time or full-time employee to support and coordinate the cultural education tasks of the settlements. It would be another important task to provide the professionals working in the area with individual or community help and support their professional development.

3. Fostering the Implementation of Quality Art Programs

Many urban cultural education institutions also operate as host theatres. A serious problem for professionals working here is to be able to provide affordable yet quality programs to their audience/ community. Yet, they do not have the financial and human resources to review the production to be ordered, and the staff are not experienced in professional art management. Cooperation among certain groups of towns (county or smaller level) would be practical to inform each other about productions that are up to the standard of quality and affordability. The cooperation of several towns would facilitate the quality control of the productions in advance and would help get involved in artistic public life more effectively, which could have other benefits as well.

We believe that these (3) improvements would also help research in the cultural field: the development of a registration system would help in the continuous monitoring of cultural institutions, and action research could be linked to new methodological developments for in-process development.

\section{Список використаної літератури}

1. 1976. évi V. törvény a közművelödésröl [1976 Act on Cultural Education]

2. 1997. évi CXL. törvény a muzeális intézményekről, a nyilvános könyvtári ellátásról és a közmüvelődésről [Act CXL. of 1997 on Museum Institutions, Public Library Services and Cultural Education]

3. 20/2018. (VII.9.) EMMI rendelet a közmüvelődési alapszolgáltatások, valamint a közmüvelödési intézmények és a közösségi színterek követelményeiröl. [20/2018. (VII. 9.) EMMI Decree on the requirements for cultural education basic services and cultural education institutions and community venues]

4. 32/2017. (XII. 12.) EMMI rendelet a kulturális szakemberek továbbképzéséröl [32/2017. (XII. 12.) EMMI Decree on the training of cultural professionals]

5. 378/2017. (XII. 11.) Korm. rendelet a kulturális szakemberek szakmai továbbképzésének nyilvántartásba vételi szabályairól [378/2017. (XII. 11.) Government Decree on rules for the registration of the professional training of cultural professionals]

6. Erika Juhász - Nikoletta Pete (2018): A közösségi művelődés képzési és továbbképzési rendszere. [Tudástár a közösségi müvelödésben online sorozat I. kötet.] [The system of training and further training in community culture. Knowledgebase in Community Culture online series Volume I] Online: https://nmi.hu/tudastar/tudastar-a-kozossegi-muvelodesben/

7. Erika Juhász (2016): A felnőttek képzése és művelődése egykor és ma Magyarországon. [The education and culture of adults once and today in Hungary] Debrecen, Csokonai Kiadó

8. Erika Juhász (2018): Kultúra és tőkê: befektetés a közösségi művelődésbe. [Culture and capital: investing in community culture.] In: SZÍN - KÖZÖSSÉGI MÜVELÖDÉS folyóirat, 3. szám, 47-50. pp.

9. József Kary et al. (2018): Útmutató a közmüvelődési szakterület megújult jogszabályi környezetének alkalmazásához. [Guide to the application of the renewed legal environment in the field of cultural education.] Budapest, Nemzeti Mủvelödési Intézet

10.Kulturális statisztika 2018. évi adatok. [Statistics on Culture. Data of 2018] URL: www.kultstat.emmi.gov.hu

11.Edina Márkus - Nikoletta Pete (2018): Civil ismeretek a közösségi művelődésben. [Tudástár a közösségi művelődésben online sorozat 11. kötet.] [Civil studies in community culture. Knowledgebase in Community Culture online series Volume 11.] Accessible: https://nmi.hu/tudastar/tudastar-a-kozossegi-muvelodesben/

12.Nemzeti Mủvelődési Intézet honlapja [Website of the National Institute of Culture]. URL: www.nmi.hu

\section{References}

1. 1976. évi V. törvény a közmüvelödésről [1976 Act on Cultural Education]. [in Hungarian].

2. 1997. évi CXL. törvény a muzeális intézményekről, a nyilvános könyvtári ellátásról és a közművelődésről [Act CXL. of 1997 on Museum Institutions, Public Library Services and Cultural Education]. [in Hungarian].

3. 20/2018. (VII.9.) EMMI rendelet a közmüvelődési alapszolgáltatások, valamint a közmúvelödési intézmények és a közösségi színterek követelményeiről. [20/2018. (VII. 9.) EMMI Decree on the requirements for cultural education basic services and cultural education institutions and community venues]. [in Hungarian].

4. 32/2017. (XII. 12.) EMMI rendelet a kulturális szakemberek továbbképzéséröl [32/2017. (XII. 12.) EMMI Decree on the training of cultural professionals]. [in Hungarian].

5. 378/2017. (XII. 11.) Korm. rendelet a kulturális szakemberek szakmai továbbképzésének nyilvántartásba vételi szabályairól [378/2017. (XII. 11.) Government Decree on rules for the registration of the professional training of cultural professionals]. [in Hungarian]

6. Juhász, E., \& Pete, N. (2018). A közösségi müvelödés képzési és továbbképzési rendszere [The system of training and further training in community culture]. Tudástár a közösségi müvelödésben, I. https://nmi.hu/tudastar/tudastar-a-kozossegimuvelodesben/ [in Hungarian].

7. Juhász, E. (2016). A felnöttek képzése és müvelödése egykor és ma Magyarországon [The education and culture of adults once and today in Hungary]. Csokonai Kiadó. [in Hungarian].

8. Juhász, E. (2018). Kultúra és tőke: befektetés a közösségi mủvelödésbe [Culture and capital: investing in community culture]. Szín Közösségi Müvelödés Folyóirat, 3, 47-50. [in Hungarian].

9. Kary, J., et al. (2018). Útmutató a közmüvelödési szakterület megújult jogszabályi környezetének alkalmazásához [Guide to the application of the renewed legal environment in the field of cultural education]. Nemzeti Mủvelődési Intézet. [in Hungarian].

10.Kulturális statisztika. (2018) [Statistics on Culture]. www.kultstat.emmi.gov.hu [in Hungarian].

11. Márkus, E., \& Pete, N. (2018). Civil ismeretek a közösségi mủvelődésben [Civil studies in community culture] Tudástár a közösségi müvelödésben, $11 \mathrm{https://nmi.hu/tudastar/tudastar-a-kozossegi-muvelodesben/} \mathrm{[in} \mathrm{Hungarian].}$

12.Nemzeti Mủvelődési Intézet honlapja (2020). [Website of the National Institute of Culture]. www.nmi.hu [in Hungarian] 
Стаття надійшла до редакції 17.09.2020 р. Стаття прийнята до друку 24.09.2020 р.

\author{
Югас Еріка \\ доктор педагогічних наук, професор \\ Інститут освіти і культури, кафедра освіти дорослих та управління культурою \\ Дебреценський Університет, Угорщина
}

Директор, старший науковий співробітник, Центр культурних досліджень та освіти національного інституту культури Угорщини

Бордаш Іштван

Президент, Асоціація менеджерів угорської культури

\title{
ОСНОВНА ХАРАКТЕРИСТИКА ОСВІТНЬОЇ КУЛЬТУРИ УГОРЩИНИ
}

Анотація. Освітня культура Угорщини - це особлива система концепцій та видів діяльності, яка є унікальною в Свропі. Ї̈і історичні корені можна простежити до першої половини 19 століття. Хоча історичні бурі останніх двох століть принесли багато перешкод для розвитку цієї системи, ми можемо стверджувати, що сьогодні ця мережа найбільш ефективно та широко виконує щоденні культурні та громадські потреби громадян Угорщини. Статистика чудово підтверджує це твердження. У нашому дослідженні зроблено спробу дати огляд характеристик та поточної ситуації в установах, що функціонують в межах місцевих органів влади. Використані методи дослідження: історичний, системний та структурно-функціональний аналіз. Аналіз базується на кількох джерелах. 3 одного боку, він враховує інформацію, яку надають обов'язкові статистичні дані. Однак особистий досвід авторів цього дослідження також не може залишатися поза увагою. Виконання завдань як професійних керівників та кваліфікованих аудиторів протягом майже двох десятиліть $€$ важливою основою висновків. На основі результатів дослідження ми сформулювали кілька пропозицій щодо професійного вдосконалення: (1) Створення системи реєстрації закладів культурної освіти, (2) Розвиток постачання культурних завдань у підрайонах, (3) Сприяння впровадженню якості мистецької програми. Ми вважаємо, що ці вдосконалення також допомогли б у культурній галузі: розробка системи реєстрації допомогла б у постійному моніторингу культурних установ, а дослідження дій могли б бути пов'язані 3 новими методологічними розробками для внутрішнього розвитку.

Ключові слова: освітня культура; дослідження; Угорщина. 